\title{
ADSORPSI ZAT WARNA METILEN BIRU DENGAN KARBON AKTIF DARI KULIT DURIAN MENGGUNAKAN KOH DAN NaOH SEBAGAI AKTIVATOR
}

\section{METHYLENE BLUE ADSORPTION BY DURIAN SHELL ACTIVATED CARBON USING KOH AND NaOH AS AN ACTIVATOR}

\author{
Farida Hanum*, Rikardo Jgst Gultom, Maradona Simanjuntak \\ Departemen Teknik Kimia, Fakultas Teknik, Universitas Sumatera Utara \\ Jl. Almamater Kampus USU Medan, 20155 Indonesia \\ Email : ida_hanum78@yahoo.co.id
}

\begin{abstract}
Abstrak
Durian merupakan tanaman daerah tropis, sehingga dapat tumbuh baik di Indonesia. Sebanyak 60-75\% bagian dari durian berupa kulit. Kulit durian bisa menjadi alternatif karbon aktif yang potensial karena kulit durian mengandung karbon yang cukup tinggi yaitu 57,42\%. Penelitian ini bertujuan untuk mengetahui pengaruh waktu kontak dan kecepatan pengadukan terhadap daya adsorpsi karbon aktif dari kulit durian dengan aktivator $\mathrm{KOH}$ dan $\mathrm{NaOH}$. Analisa FTIR (Fourier Transform Infra Red) menunjukkan proses aktivasi mempengaruhi intensitas serapan di daerah panjang gelombang dan mengakibatkan terbentuknya pita $C=C$ aromatik, sehingga sifat karbon aktif tersebut menjadi lebih polar dibandingkan dengan kondisi awalnya. Analisa dilakukan dengan menggunakan alat Spektrofotometer UV-Vis untuk mengetahui nilai absorbansi dan konsentrasi akhir dari tiap variasi waktu kontak dan kecepatan pengadukan. Hasil penelitian menunjukkan kapasitas adsorpsi maksimum dengan aktivator $\mathrm{KOH}$ dan $\mathrm{NaOH}$ berturut-turut pada kecepatan pengadukan $150 \mathrm{rpm}$ dan waktu kontak 90 menit yaitu sebesar 3,92 mg/g dan 3,8 mg/g. Luas permukaan maksimum yang diperoleh dengan aktivasi $\mathrm{KOH}$ dan $\mathrm{NaOH}$ berturut-turut pada kecepatan pengadukan $130 \mathrm{rpm}$ dan waktu kontak 120 menit yaitu sebesar 1785,263 $\mathrm{m}^{2} / \mathrm{g}$ dan $1730,332 \mathrm{~m}^{2} / \mathrm{g}$. Luas permukaan maksimum yang diperoleh dari penelitian ini telah memenuhi standar baku luas permukaan adsorben komersial yaitu $800-1800 \mathrm{~m}^{2} / \mathrm{g}$. Pemodelan pseudo orde dua menyajikan data adsorpsi lebih presentatif terhadap data laju adsorpsi penelitian, persamaan orde dua didasarkan pada asumsi bahwa adsopsi melibatkan proses kimia.
\end{abstract}

Kata kunci: FTIR, kulit durian, kapasitas adsopsi, luas permukaan, Spektrofotometer UV-Vis

\begin{abstract}
Durian is a kind of tropical fruits which can grow well in Indonesia. Durian is containing 60-75\% shell. Durian shell could be a potential alternative to activated carbon because it contains $57.42 \%$ carbon. The aim of this research is to know the effect of contact time and stirring speed to activated carbon adsorption capacity from durian shell with $\mathrm{KOH}$ and $\mathrm{NaOH}$ as activators. FTIR (Fourier Transform Infra Red) analysis showed the activation process effects on absorption intensity wavelength region and resulted in formation of $C=C$ aromatic tape, so that the nature of the charcoal becomes more polar compared with the initial condition. Analysis using spectrophotometer UV-Vis to determine absorbance and final concentration of each variation of contact time and stirring speed. The results showed that the maximum adsorption capacity obtained by activation of $\mathrm{KOH}$ and $\mathrm{NaOH}$ on stirring speed of $150 \mathrm{rpm}$ and a contact time of 90 minutes is equal to $3.92 \mathrm{mg} / \mathrm{g}$ and $3.8 \mathrm{mg} / \mathrm{g}$ respectively. The maximum surface area obtained by activation of $\mathrm{KOH}$ and $\mathrm{NaOH}$ during the stirring speed $130 \mathrm{rpm}$ and a contact time of 120 minutes is equal to $1785.263 \mathrm{~m} 2 / \mathrm{g}$ and $1730.332 \mathrm{~m} 2 / \mathrm{g}$ respectively. The maximum surface area obtained from this research has met the standards of commercial activated carbon surface area was between 800$1800 \mathrm{~m}^{2} / \mathrm{g}$. Modeling pseudo second order presents a more representative adsorption data, a second order equation is based on the assumption that adsorption step is chemosorption.
\end{abstract}

Keywords: FTIR, durian shell, adsorption capacity, surface area, spectrophotometer UV-Vis

\section{Pendahuluan}

Sumatera Utara merupakan penghasil buah durian terbesar di Indonesia. Produksi durian di Sumatera Utara sebesar 579,471 ton pertahun. Dari satu buah durian $57 \%$ adalah kulit, sehingga di khawatirkan menjadi sampah jika tidak dimanfaatkan [12]. Kulit durian bisa menjadi alternatif karbon aktif yang potensial karena kulit durian mengandung karbon yang cukup tinggi yaitu 57,42 \%. Kandungan daging buah durian merupakan $20-35 \%$ dari berat buah, sedangkan bijinya 5$15 \%$, sisanya berupa kulit $60-75 \%$ [12].

Tabel 1 menunjukkan komposisi kimia dari kulit durian [8]. 
Tabel 1. Komposisi Kimia Kulit Durian.

\begin{tabular}{|c|c|}
\hline Senyawa & Komposisi (\%) \\
\hline Karbon & 57,42 \\
\hline Oksigen & 31,94 \\
\hline Hidrogen & 1,13 \\
\hline Nitrogen & 8,41 \\
\hline Sulfur & 1,10 \\
\hline
\end{tabular}

\section{Teori}

Secara umum adsorpsi dapat diartikan sebagai peristiwa fisika pada permukaan suatu bahan, yang tergantung dari spesifikasi antara adsorben dengan zat yang diserap (adsorbat). Adsorpsi yang terjadi pada permukaan adsorben dapat bersifat adsorpsi fisika (adsorpsi Van der Waals) atau adsorpsi kimia (chemisorption). Adsorpsi fisik terjadi akibat adanya perbedaan energi atau gaya tarik bermuatan listrik (gaya van der Walls) [7].

Kinetika adsorpsi merupakan laju penyerapan suatu fluida oleh adsorben dalam jangka waktu tertentu. Untuk menyelidiki proses adsorpsi logam berat, model kinetik yang berbeda digunakan untuk menggambarkan tingkat penyerapan adsorbat pada adsorben. Pada berbagai penelitian, data kinetika adsorsi diperoleh secara empiris dengan menggunakan model persamaan orde satu, persamaan orde dua dan model Elovich. Tujuannya untuk mempelajari kinetika adsorpsi dan menemukan model terbaik yang cocok untuk data eksperimen [8].

\section{Metodologi Penelitian}

Bahan yang digunakan dalam penelitian ini adalah kulit durian, metilen biru, aquadest, larutan $\mathrm{KOH}$, larutan $\mathrm{NaOH}$. Peralatan yang digunakan dalam penelitian ini meliputi Spektrofotometer UV-Vis, FTIR (Fourier Transform Infra Red), oven, furnace, ayakan, desikator, shaker, kertas saring whatman 42, beaker glass, batang pengaduk, corong gelas, pipet tetes, stopwatch.

Pembuatan Karbon aktif kulit durian pertama dilakukan dengan cara membersihkan kulit durian dari kotoran yang terikut, kemudian dipotong-potong hingga ukurannya sebesar $3 \times 3$ $\mathrm{cm}$. Kulit durian kemudian digiling menjadi serbuk dengan ball mill, serbuk kulit durian direndam dalam larutan $\mathrm{KOH} 2 \%$ kemudian diaduk dan dijaga dengan suhu larutan $85^{\circ} \mathrm{C}$ selama 1 jam. Serbuk kulit durian kemudian dikeringkan selama 24 jam pada suhu $60^{\circ} \mathrm{C}$. Serbuk kulit durian diayak dengan ayakan yang berukuran 50 - 60 mesh, hasil ayakan yang lolos dipanaskan pada suhu $600^{\circ} \mathrm{C}$ menggunakan furnace selama 2 jam, setelah itu hasil pemanasan disimpan dalam desikator selama 24 jam.

Penentuan gugus fungsi kulit durian dilakukan dengan perangkat alat uji FTIR. Penentuan Luas Permukaan Karbon aktif dan Kapasitas Adsorpsi Karbon aktif dilakukan dengan cara: sebanyak $0,5 \mathrm{~g}$ sampel serbuk kulit durian dengan waktu aktivasi 1 jam ukuran 50 60 mesh kemudian ditambahkan ke dalam 100 $\mathrm{ml}$ larutan metilen biru $30 \mathrm{ppm}$. Kemudian larutan tersebut diaduk dengan shaker dengan kecepatan pengadukan 90 rpm selama 30 menit. Hasil pengadukan disaring dengan menggunakan kertas saring. Kemudian diukur nilai adsorbansi filtratnya dengan menggunakan Spektrofotometer UV-Vis. Hasil pengukuran akan berupa konsentrasi metilen biru. Banyaknya metilen biru yang terjerap oleh setiap g sampel dapat dihitung dengan rumus persamaan kapasitas adsorpsi:

$$
\text { Wads }=\frac{C 1-C 2}{1000} \times \mathrm{V} \times \frac{1}{B}
$$

Keterangan :

$\mathrm{W}_{\mathrm{ads}}=$ berat metilen biru yang $(\mathrm{mg} / \mathrm{g})$

$\mathrm{B}=$ berat sampel yang digunakan $(\mathrm{g})$

$\mathrm{C}_{1}=$ konsentrasi larutan metilen biru awal (ppm)

$\mathrm{C}_{2}=$ konsentrasi larutan metilen biru akhir (ppm)

$\mathrm{V} \quad=$ volume larutan metilen biru yang digunakan $(\mathrm{ml})$

Berat teradsorpsi maksimum dimasukkan ke dalam persamaan sehingga didapatkan luas permukaan karbon aktif:

$$
\mathrm{S}=\frac{\mathrm{X}_{\mathrm{m}} \cdot \mathrm{N} \cdot \mathrm{a}}{\mathrm{M}_{\mathrm{r}}}
$$

Keterangan:

$$
\begin{aligned}
& \mathrm{S}= \text { luas permukaan karbon aktif }\left(\mathrm{m}^{2} / \mathrm{g}\right) \\
& \mathrm{N}= \text { bil. Avogrado }\left(6,022 \times 1023 \mathrm{~mol}^{-1}\right) \\
& \mathrm{Xm}= \text { berat adsorbat teradsorpsi } \\
&(\mathrm{mg} / \mathrm{g}) \\
& \mathrm{a}= \text { luas penutupan oleh } 1 \text { molekul } \\
& \text { sampel }\left(197 \times 10-20 \mathrm{~m}^{2}\right) \\
& \mathrm{Mr}= \begin{array}{l}
\text { massa molekul relatif metilen biru } \\
\end{array} \\
&(320,5 \mathrm{~g} / \mathrm{mol})
\end{aligned}
$$

Percobaan diulangi untuk variasi pengadukan (110 rpm, $130 \mathrm{rpm}$ dan $150 \mathrm{rpm}$ ) dan waktu kontak (60 menit, 90 menit dan 120 menit).

Penentuan kinetika adsorpsi pada penelitian ini dilakukan dengan variasi waktu kontaknya adalah 80 menit, 90 menit, 100 menit, 110 menit, 120 menit, 130 menit, 140 menit, 150 menit, dan 160 menit. Larutan metilen biru yang digunakan pada analisis optimasi waktu kontak ini adalah $30 \mathrm{ppm}$. Berat kulit durian yang 
digunakan adalah 0,5 g dengan ukuran kulit durian 50-60 mesh.

\section{Hasil dan Pembahasan}

\section{Penentuan Gugus Fungsi Kulit Durian}

Pengujian FTIR dilakukan untuk melihat dan mendeteksi gugus-gugus fungsi senyawa organik pada sampel. Hasil pengujian FTIR sampel karbon aktif sebelum dan setelah aktivasi $\mathrm{KOH} 2 \%$ dapat dilihat pada Gambar 1.

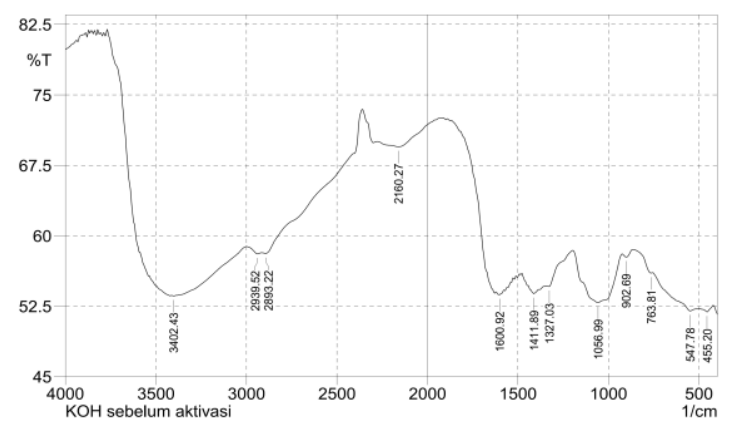

(a)

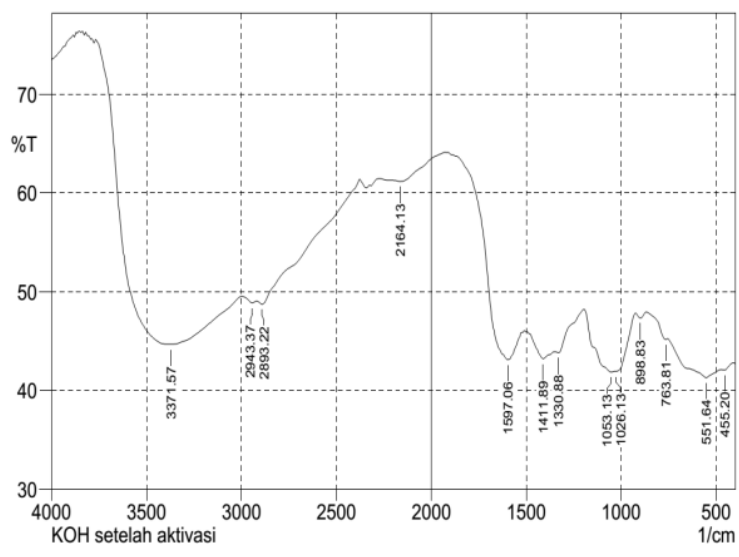

(b)

Gambar 1 (a). Hasil Analisis FTIR pada Karbon Aktif Kulit Durian Sebelum Aktivasi, 1(b). Hasil Analisis FTIR pada Karbon Aktif Kulit Durian Setelah Aktivasi KOH $2 \%$.

Dari gambar 1(a) dapat dilihat bahwa Spektrum FTIR karbon aktif dari kulit durian yang tidak diaktivasi menunjukkan adanya vibrasi gugus fungsi $\mathrm{O}-\mathrm{H}, \mathrm{C}-\mathrm{H}, \mathrm{C}-\mathrm{C}$ dan $\mathrm{C}=\mathrm{C}$ dari senyawa aromatik yang ditunjukkan dengan adanya pita serapan di daerah panjang gelombang $455.2 \mathrm{~cm}^{-1}-3402.43 \mathrm{~cm}^{-1}$.

Dari gambar 1(b) dapat dilihat bahwa spektrum FTIR pada karbon aktif yang diaktivasi dengan $\mathrm{KOH} 2 \%$ terjadi perubahan gugus fungsi yang ditunjukkan dengan terbentuknya pita $\mathrm{C}=\mathrm{C}$ aromatik di daerah panjang gelombang $1026.13 \mathrm{~cm}^{-1}-1053.13 \mathrm{~cm}^{-1}$ dan perubahan gugus fungsi $\mathrm{C}-\mathrm{H}$ terjadi karena adanya pergeseran panjang gelombang dari $3402.43 \mathrm{~cm}^{-1}$ menjadi $3371.57 \mathrm{~cm}^{-1}$. Hasil pengujian FTIR sampel karbon aktif sebelum dan setelah aktivasi $\mathrm{NaOH} 2 \%$ dapat dilihat pada Gambar 2

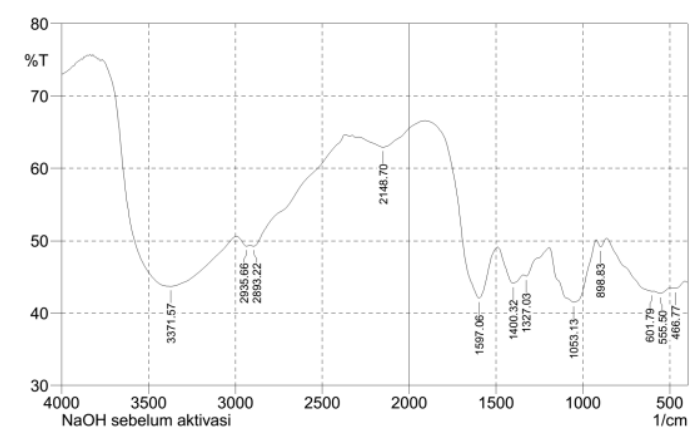

(a)

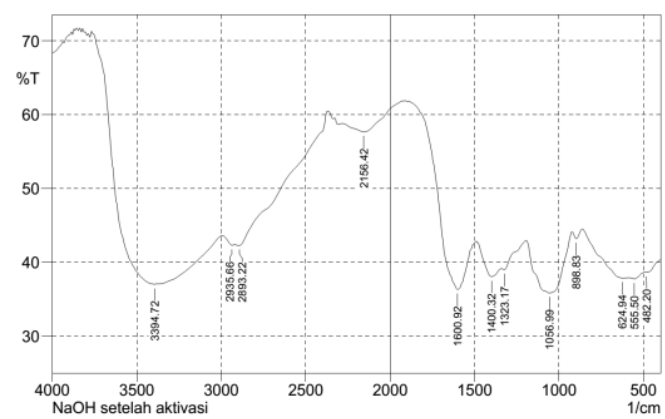

(b)

Gambar 2 (a). Hasil Analisis FTIR pada Karbon Aktif Kulit Durian Sebelum Aktivasi 2 (b. )Hasil Analisis FTIR pada Karbon Aktif Kulit Durian Setelah Aktivasi NaOH $2 \%$.

Dari gambar 2(a) dapat dilihat bahwa Spektrum FTIR karbon aktif dari kulit durian yang tidak diaktivasi menunjukkan adanya vibrasi gugus fungsi $\mathrm{O}-\mathrm{H}, \mathrm{C}-\mathrm{H}, \mathrm{C}-\mathrm{C}$ dan $\mathrm{C}=\mathrm{C}$ dari senyawa aromatik yang ditunjukkan dengan adanya pita serapan di daerah panjang gelombang $466.77 \mathrm{~cm}^{-1}-3371.57 \mathrm{~cm}^{-1}$. Pita lebar dengan intensitas kuat pada daerah $3371.57 \mathrm{~cm}^{-1}$ menunjukkan adanya ikatan $\mathrm{O}-\mathrm{H}$ dan C-H. Pita pada daerah $1053.13 \mathrm{~cm}^{-1}$ menunjukkan adanya ikatan $\mathrm{C}=\mathrm{C}$ aromatik, dan pada daerah $466.77 \mathrm{~cm}^{-1}-1400.32 \mathrm{~cm}^{-1}$ menunjukkan adanya ikatan C-C.

Dari gambar 2(b) dapat dilihat bahwa spektrum FTIR pada karbon aktif yang diaktivasi dengan $\mathrm{NaOH} 2 \%$ terjadi perubahan gugus fungsi yang ditunjukkan dengan terbentuknya pita $\mathrm{C}=\mathrm{C}$ aromatik di daerah panjang gelombang $1323.17 \mathrm{~cm}^{-1}-1400.32 \mathrm{~cm}^{-}$ dan perubahan gugus fungsi $\mathrm{C}-\mathrm{H}$ terjadi 
karena adanya pergeseran panjang gelombang dari $3371.57 \mathrm{~cm}^{-1}$ menjadi $3394.72 \mathrm{~cm}^{-1}$

Aktivasi lebih lanjut menyebabkan hilangnya gugus karbonil disusul dengan terbentuknya $\mathrm{C}=\mathrm{C}$ aromatic [7], yang masingmasing ditunjukkan oleh pergeseran panjang gelombang gugus fungsi C-H dari $3402.43 \mathrm{~cm}^{-1}$ menjadi $3371.57 \mathrm{~cm}^{-1}$ dan terbentuknya pita di daerah panjang gelombang $1026.13 \mathrm{~cm}^{-1}$ $1053.13 \mathrm{~cm}^{-1}$.

Berdasarkan pola spektrum FTIR terlihat bahwa proses aktivasi mempengaruhi intensitas serapan di daerah panjang gelombang dan mengakibatkan terjadinya perubahan struktur gugus fungsi. Hal ini menunjukkan bahwa struktur permukaan arang aktif masih mengandung ikatan $\mathrm{C}-\mathrm{O}$ dan $\mathrm{C}-\mathrm{H}$ serta terbentuknya pita $\mathrm{C}=\mathrm{C}$ aromatik, yang mengakibatkan berubahnya sifat karbon tersebut menjadi lebih polar dibandingkan dengan kondisi awalnya [6].

\section{Pengaruh Waktu Kontak Dan Kecepatan Pengadukan Terhadap Kapasitas Adsorpsi}

Kapasitas adsorpsi adalah salah satu parameter penentuan karbon aktif yang baik. Waktu kontak mempengaruhi kapasitas adsorpsi karena waktu kontak merupakan faktor yang dapat merefleksikan kinetika suatu karbon aktif dalam berinteraksi dengan adsorbat [9].

Pengaruh waktu kontak dan kecepatan pengadukan terhadap kapasitas adsorpsi karbon aktif dengan aktivasi $\mathrm{KOH}$ dan $\mathrm{NaOH}$ berturutturut dapat dilihat pada gambar 3 dan gambar 4.

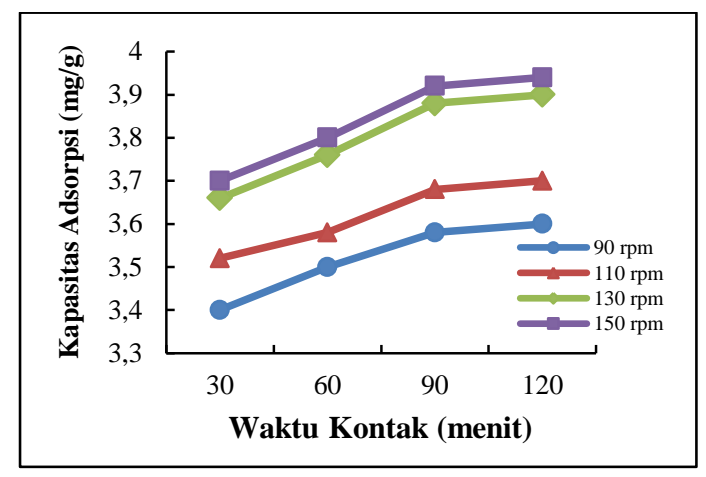

Gambar 3. Pengaruh Waktu Kontak dan Kecepatan Pengadukan Terhadap Kapasitas Adsorpsi Karbon Aktif dengan Aktivator KOH.

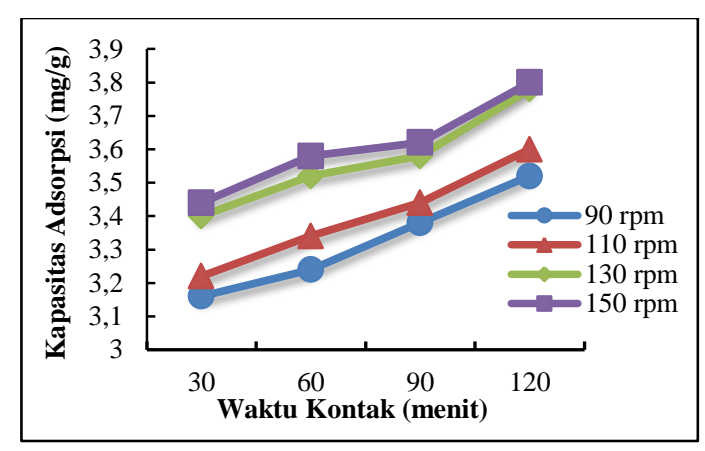

Gambar 4. Pengaruh Waktu Kontak Dan Kecepatan Pengadukan Terhadap Kapasitas Adsorpsi Karbon Aktif dengan Aktivator $\mathrm{NaOH}$.

Gambar 3 dan gambar 4 menunjukkan kapasitas adsorpsi maksimum dengan aktivator $\mathrm{KOH}$ dan $\mathrm{NaOH}$ berturut-turut pada kecepatan pengadukan $150 \mathrm{rpm}$ dan waktu kontak 90 menit yaitu sebesar $3,92 \mathrm{mg} / \mathrm{g}$ dan $3,8 \mathrm{mg} / \mathrm{g}$, Sedangkan kapasitas adsorpsi minimum dengan aktivator $\mathrm{KOH}$ dan $\mathrm{NaOH}$ berturut-turut pada kecepatan pengadukan $90 \mathrm{rpm}$ dan waktu kontak 30 menit yaitu sebesar $3,4 \mathrm{mg} / \mathrm{g}$ dan $3,16 \mathrm{mg} / \mathrm{g}$.

Aktivator $\mathrm{KOH}$ lebih baik dan efektif dibandingkan aktivator $\mathrm{NaOH}$ dalam memutus rantai karbon dari senyawa organik pada kulit durian sehingga meningkatkan jumlah unsur karbon selama proses aktivasi. Semakin banyak jumlah karbon, maka semakin banyak pori pori yang bisa terbentuk untuk menjerap adsorbat dan akan meningkatkan kapasitas adsorpsi [2].

Dari hasil analisis yang dilakukan, pengaruh waktu kontak terhadap kapasitas adsorpsi cenderung memiliki bentuk atau model yang sama pada berbagai variasi kecepatan pengadukan. kapasitas adsorpsi semakin besar seiring bertambahnya waktu kontak dari 30 120 menit pada berbagai variasi kecepatan pengadukan. Secara umum perubahan kapasitas adsorpsi terbesar terjadi mulai dari waktu 30 90 menit sedangkan dari waktu $90-120$ menit nilai kapasitas adsorpsi cenderung mendekati nilai konstan. Hal ini terjadi karena pada awal proses adsorpsi, pori - pori karbon aktif masih terbebas dari partikel adsorbat dan peluang partikel adsorbat untuk terjerap kedalam pori pori karbon aktif masih sangat besar sehingga perubahan kapasitas adsorpsi pada tahap awal adsorpsi cukup besar [9].

Berdasarkan hasil penelitian sebelumnya, karbon aktif kulit durian memiliki diameter pori yaitu sekitar $\pm 20 \mu \mathrm{m}$ [10]. Ini menunjukkan bahwa karbon aktif kulit durian memiliki diameter pori yang cukup besar jika dibandingkan dengan standard karbon aktif 
komersial, sehingga proses adsorpsi sampai menuju kesetimbangan berlangsung cepat.

\section{Pengaruh Waktu Kontak Dan Kecepatan Pengadukan Terhadap Luas Permukaan}

Penentuan luas permukaan adsorben kulit durian, pertama dilakukan dengan menentuan panjang gelombang maksimum untuk larutan metilen biru dengan menggunakan spektrofotometer UV-Vis. Pada larutan metilen biru dengan konsentrasi 30 ppm dihasilkan panjang gelombang maksimum pada $664 \mathrm{~nm}$, yaitu pada absorbansi maksimum. Grafik konsentrasi larutan metilen biru terhadap absorbansi dapat dilihat pada gambar 5

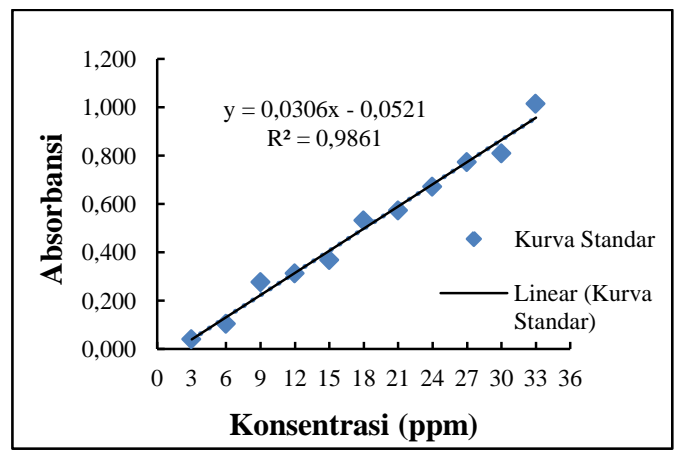

Gambar 5. Kurva Kalibrasi Larutan Metilen Biru

Persamaan regresi kurva standar metilen biru dinyatakan sebagai $\mathrm{y}=\mathrm{a}+\mathrm{bx}$, dengan $\mathrm{y}$ adalah absorbansi dan $\mathrm{x}$ adalah konsentrasi larutan metilen biru. Korelasi sempurna jika nilai $\mathrm{R}^{2}$ mendekati 1 . Berdasarkan data dan perhitungan didapatkan persamaan regresi linier larutan standar metilen biru adalah $\mathrm{y}=0.0306 \mathrm{x}$ - 0.0521dengan nilai $R^{2}=0,9861$. Harga $R$ yang diperoleh mendekati 1, maka dapat disimpulkan bahwa nilai koefisien korelasi.

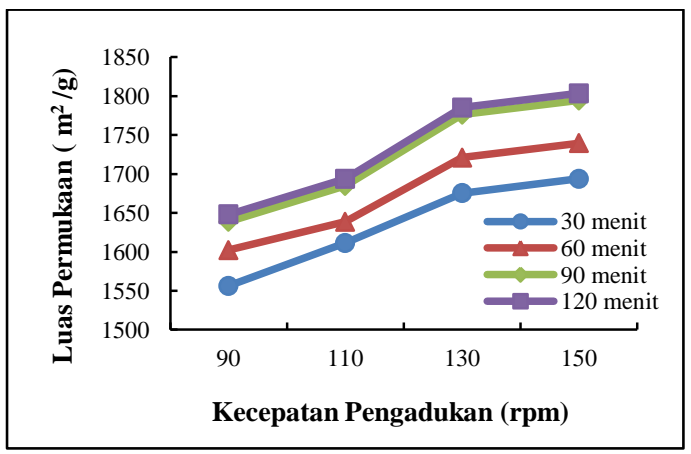

Gambar 6. Pengaruh Waktu Kontak dan Kecepatan Pengadukan terhadap Luas Permukaan Karbon Aktif dengan Aktivator KOH.

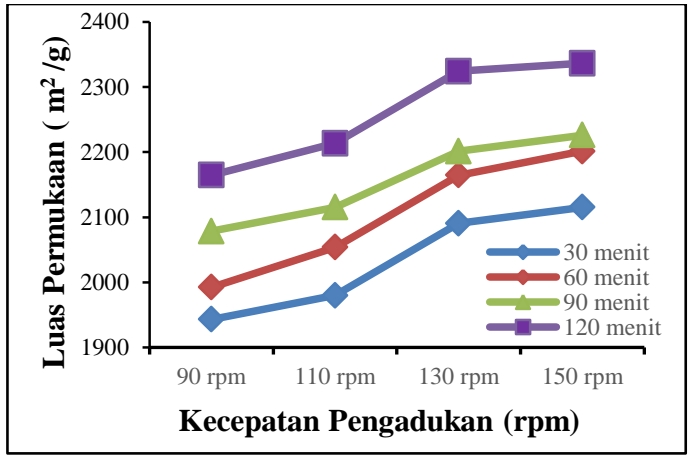

Gambar 7. Pengaruh Waktu Kontak Dan Kecepatan Pengadukan Terhadap Luas Permukaan Karbon Aktif dengan Aktivator $\mathrm{NaOH}$.

Pengaruh Waktu Kontak dan Kecepatan Pengadukan terhadap Luas Permukaan Karbon Aktif dengan Aktivator $\mathrm{KOH}$ dan $\mathrm{NaOH}$ berturut-turut dapat dilihat pada gambar 6 dan gambar 7. Gambar 6 dan gambar 7 menunjukkan luas permukaan maksimum dengan aktivasi $\mathrm{KOH}$ dan $\mathrm{NaOH}$ berturut-turut pada kecepatan pengadukan $130 \mathrm{rpm}$ dan waktu kontak 120 menit yaitu sebesar 1785,263 $\mathrm{m}^{2} / \mathrm{g}$ dan $1730,332 \mathrm{~m}^{2} / \mathrm{g}$, sedangkan luas permukaan minimum dengan aktivasi $\mathrm{KOH}$ dan $\mathrm{NaOH}$ berturut-turut pada kecepatan pengadukan 90 rpm dan waktu kontak 30 menit yaitu sebesar $1556,383 \mathrm{~m}^{2} / \mathrm{g}$. dan $1446,521 \mathrm{~m}^{2} / \mathrm{g}$.

Aktivator $\mathrm{KOH}$ menghasilkan rasio volume mikropori/volume total pori lebih besar dari pada aktivator $\mathrm{NaOH}$ pada rasio activating agent:sampel yang sama. Pembentukan poripori ini akan memperbesar luas permukaan karbon aktif yang diperoleh sehingga efisiensi adsorpsinya pun akan meningkat [12].

Aktivasi kimia dengan $\mathrm{KOH}$ melibatkan reaksi kimia sebagai berikut:

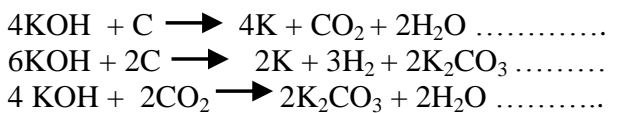

Reaksi di atas juga mengeluarkan air yang terjebak pada rongga karbon karena $\mathrm{KOH}$ merupakan dehydrating agent/bersifat mendehidrasi, sehingga panas yang digunakan akan semakin efektif dalam pembentukan poripori baru dan permukaan karbon aktif akan semakin luas [12].

Berdasarkan hasil penelitian ini karbon aktif kulit durian memiliki luas permukaan maksimum 1785,263 $\mathrm{m}^{2} / \mathrm{g}$. Standard karakteristik adsorben, adsorben yang baik dan dapat dipergunakan untuk jenis Powdered 
Activatid Carbon (PAC) harus memiliki luas permukaan $800 \mathrm{~m}^{2} / \mathrm{g}-1800 \mathrm{~m}^{2} / \mathrm{g}$. Hasil penelitian menunjukkan bahwa luas permukaan adsorben yang diperoleh telah sesuai dengan nilai luas permukaan adsorben komersil [12].

\section{Kinetika Adsorpsi}

Penentuan kinetika adsorpsi pada penelitian ini dilakukan dengan variasi waktu kontaknya adalah 0 - 220 menit. Larutan metilen biru yang digunakan pada analisis penentuan waktu kontak maksimum ini adalah $30 \mathrm{ppm}$. Berat kulit durian kulit durian yang digunakan adalah 0,5 g dengan ukuran kulit durian 50-60 mesh. Dari data yang diperoleh dapat dibuat hubungan antara waktu kontak dengan konsentrasi metilen biru yang teradsorpsi dari larutan metilen biru, seperti yang disajikan pada Gambar 8

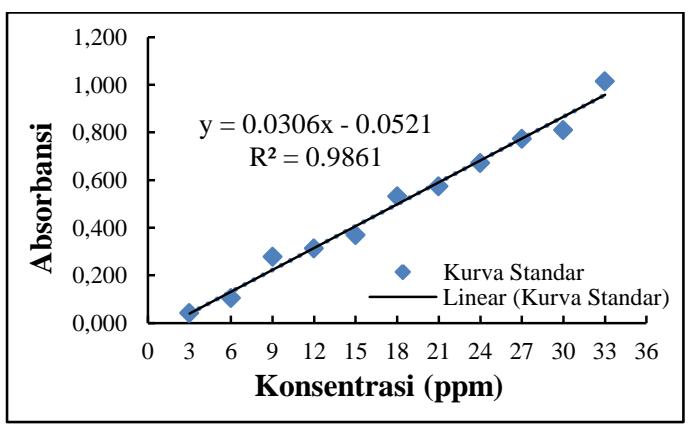

Gambar 8. Persentase Adsorpsi dengan Konsentrasi Larutan 30 ppm pada Ukuran Kulit durian 50-60 mesh serta Kecepatan Pengadukan 130 rpm.

Data kinetika adsorpsi diperoleh secara empiris dengan menggunakan model pseudo orde satu dan pseudo orde dua. Pengujian model kesetimbangan dilakukan untuk menentukan model kesetimbangan yang sesuai digunakan pada suatu penelitian. Penentuan model kesetimbangan tergantung pada harga koefisien korelasi $\left(\mathrm{R}^{2}\right)$. Model kesetimbangan yang cocok adalah model kesetimbangan dengan harga $R^{2}$ yang lebih tinggi atau mendekati 1 [12]. Adapun persamaan pseudo orde satu dan orde dua tersebut berturut-turut dapat dilihat sebagai berikut :

$$
\begin{aligned}
& \frac{1}{q_{t}}=\frac{k_{t}}{\left(q_{e}\right) t}+\frac{1}{q_{e}} \ldots \\
& \frac{t}{q_{t}}=\frac{t}{q_{e}}+\frac{1}{\left(k_{2} q_{e}^{2}\right)}
\end{aligned}
$$

Koefisien korelasi, diperoleh dengan cara melakukan plot data kapasitas adsorpsi $\left(\mathrm{q}_{\mathrm{t}}\right)$ terhadap waktu dengan menggunakan persamaan di atas, sehingga diperoleh grafik seperti Gambar 9 dan 10

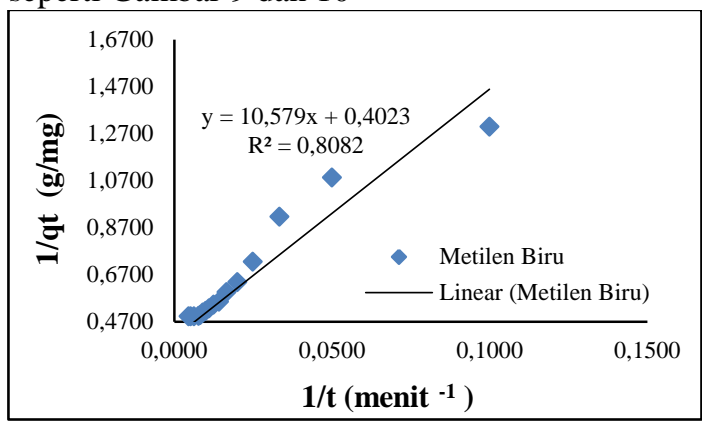

Gambar 9. Pemodelan Pseudo Orde Satu pada Konsentrasi Larutam Metilen Biru 30 ppm dan Kecepatan Pengadukan 130 rpm.

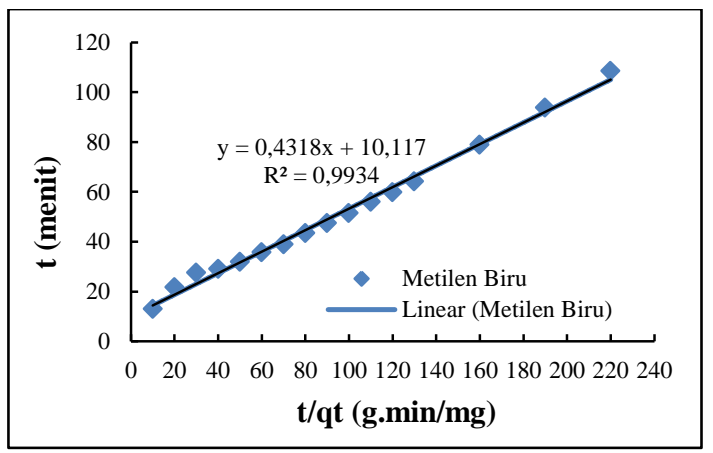

Gambar 10. Pemodelan Pseudo Orde Dua pada Konsentrasi Larutam Metilen Biru 30 ppm dan Kecepatan Pengadukan 130 rpm.

Nilai koefisien korelasi $\left(\mathrm{R}^{2}\right)$ orde dua lebih mendekati angka satu (1) dibandingkan dengan orde satu. Jika harga $\mathrm{R}^{2}$ pada pseudo orde satu lebih besar dan mendekati nilai 1 dari harga $\mathrm{R}^{2}$ pada pseudo orde dua maka adsorpsi melibatkan reaksi fisika dan jika harga $\mathrm{R}^{2}$ pada pseudo orde dua lebih besar dan mendekati nilai 1 dari harga $\mathrm{R}^{2}$ pada pseudo orde satu maka adsorpsi melibatkan reaksi kimia. Data laju adsorpsi pada penelitiaan ini menunjukkan bahwa pemodelan pseudo orde dua menyajikan model laju adsorpsi yang lebih presentatif, persamaan orde dua didasarkan pada asumsi bahwa adsorpsi melibatkan proses kimia antara adsorben dan adsorbat [3].

\section{Kesimpulan}

Berdasarkan hasil penelitian dan pembahasan maka dapat disimpulkan bahwa karbon aktif dengan aktivator $\mathrm{KOH}$ dengan kapasitas adsorpsi maksimum 3,92 mg/g dan luas permukaan maksimum 1785,263 $\mathrm{m}^{2} / \mathrm{g}$ memiliki daya serap yang lebih baik untuk menyerap metilen biru dibandingkan karbon aktif dengan aktivator $\mathrm{NaOH}$ dengan kapasitas 
adsorpsi maksimum adalah $3,8 \mathrm{mg} / \mathrm{g}$ dan luas permukaan maksimum $1732,345 \mathrm{~m}^{2} / \mathrm{g}$. Karbon aktif dengan aktivator $\mathrm{KOH}$ dan $\mathrm{NaOH}$ memiliki luas permukaan maksimum masing masing adalah $1785,263 \mathrm{~m}^{2} / \mathrm{g}$ dan $1732.345 \mathrm{~m}^{2}$ $/ g$ dan telah memenuhi standar untuk luas permukaan adsorben komersial. Pemodelan pseudo orde dua menyajikan model laju adsorpsi yang lebih presentatif terhadap data adsorpsi pada penelitian ini, persamaan orde dua didasarkan pada asumsi bahwa adsorpsi melibatkan proses kimia antara adsorben dan adsorbat.

\section{Daftar Pustaka}

[1] A. Shende, Effect Of Contact Time On Adsorption Of Nitrates And Phosphates, International Journal of Advanced Technology in Engineering and Science, Volume No.02, Issue No. 07, July. 2014.

[2] A. Monge, Insight Into HydroxidesActivated Coals: Chemical or Physical Activation, International Journal of Colloid and Interface Science 318 (2008) 3541.2008.

[3] B. Agarwal, P. Sengupta, Equilibrium, Kinetic and Thermodynamic Studies of Simultaneous Co-Adsorptive Removal of Phenol and Cyanide Using Chitosan, International Journal of Chemical, Molecular, Nuclear, Materials and Metallurgical Engineering Vol:7, No:11, 2013.

[4] Chandra, Adsorption Of Basic Dye Onto Activated Carbon Prepared From Durian Shell: Studies Of Adsorption Equilibrium And Kinetics, Chemical Engineering Journal 127 (2007) 121-129. 2006.

[5] Drastinawati, Pengaruh Kecepatan Pengadukan dan Temperatur terhadap Konstanta Kecepatan Adsorpsi $\mathrm{Cu}^{2+}$ dengan Arang Aktif Cangkang Sawit Sisa Pembuatan Asap Cair, Jurusan Teknik Kimia, Universitas Riau, Jurnal Teknobiologi, IV(1) 2013: 47 - 53. 2013.

[6] G. Pari, K. Sofyan, Pengaruh Lama Aktivasi Terhadap Struktur Kimia Dan Mutu Arang Aktif Serbu, Jurnal Teknik Pomits Vol. 2, No. 1, (2013) ISSN: 23373539 (2301-9271 Print), 2013.

[7] Hamdaoui, M Chiha, Removal of Methylene Blue from Aqueous Solutions by Wheat Bran, Acta Chim, 54 : 407-418, 2006.

[8] Hameed, K.Y. Foo, Textural Porosity, Surface Chemistry And Adsorptive Properties Of Durian Shell Derived
Activated Carbon Prepared By Microwave Assisted $\mathrm{NaOH}$ Activation, Chemical Engineering Journal 187 (2012) 53-622012.

[9] I. Safrianti, N. Wahyuni, Adsorpsi Timbal (II) oleh Selulosa Limbah Jerami Padi Teraktivasi Asam Nitrat : Pengaruh pH dan Waktu Kontak, ISSN 2303-1077, Vol. 1 No. 1 (2012). hal: 1-7.

[10] Kartini, A Netty, Analisis Variasi Waktu dan Kecepatan Pengadukan pada Proses Adsorbsi Logam Berat dengan Arang Aktif, INFO TEKNIK, Volume 12 No. 1, Juli 2011.

[11] M. Saber Tehrani, Removal of Lead Ions from Wastewater Using Functionalized Multiwalled Carbon Nanotubes with Tris(2-Aminoethyl) Amine, Journal of Environmental Protection, 2013, 4, 529536.

[12] Tan, Hameed, Ahmad, Equilibrium And Kinetic Studies On Basic Dye Adsorption By Oil Palm Fibre Activated Carbon, Chemical Engineering Journal 127 (2007) 111-119.

[13] T. George, L. Burton Franklin, Stensel David, Wastewater Engineering Treatment and Reuse, Fourth Edition. McGraw-Hill Companies, Inc. 2003, hal. 1138

[14] W. Mahatmanti, Optimalisasi Olahan Buah Durian Sebagai Produk Alternatif Dalam Usaha Agrowisata Durian, Prodi Kimia, Jurusan Kimia FMIPA, Universitas Negeri Semarang. 